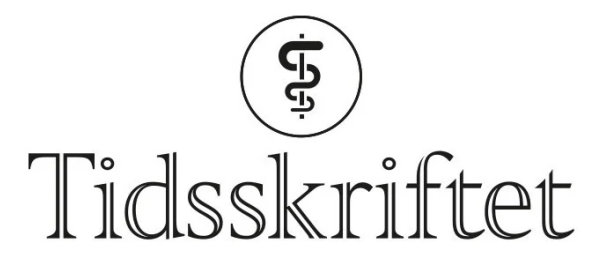

DEN NORSKE LEGEFORENING

\title{
Cerebral MR ved Parkinsons sykdom
}

\author{
NYHETER
}

MONA K. BEYER

Email: bemk@sus.no

Nasjonalt kompetansesenter for bevegelsesforstyrrelser

Stavanger universitetssjukehus

\section{Pasienter med Parkinsons sykdom har volumetriske forandringer i sideventriklene ved cerebral MR.}

Ved Alzheimers sykdom oppstår tidlige forandringer i hjernen i hippocampus og mediale temporallapp, noe som bl.a. bidrar til hukommelsessvikt. Ved Parkinsons sykdom, derimot, der den kognitive svikten ofte har en annen profil enn ved Alzheimers sykdom, er det ennå ikke etablert et mønster for hvilke hjerneforandringer som bidrar til den kognitive svikten. Vi har i tidligere studier ikke påvist noe entydig mønster mellom forandringer i hvit og grå substans og demens og kognitiv svikt.

I en ny studie brukte vi T1-vektede volumetriske MR-opptak av 27 pasienter med Parkinsons sykdom med $(n=15)$ eller uten $(n=12)$ demens og åtte pasienter med Parkinsons sykdom og mild kognitiv svikt (1). 20 friske kontrollpersoner ble også undersøkt. Gjennom et samarbeid med ledende forskere ved University of California, Los Angeles, fikk vi tilgang til å bruke avanserte volumetriske metoder for å studere regional atrofi i hippocampus, nucleus caudatus og sideventriklene.

Vi fant signifikante forskjeller med økt ventrikkelstørrelse i bakre del av sideventriklene bilateralt hos pasienter med Parkinsons sykdom og demens sammenliknet med dem med Parkinsons sykdom, samt regional atrofi i nucleus caudatus hos pasienter med Parkinsons sykdom og demens.

Regionale volumetriske forandringer i bl.a. sideventriklene kan bli en nyttig markør for sykdomsprogrediering og utvikling av kognitiv svikt hos pasienter med Parkinsons sykdom. Større pasientgrupper bør følges over tid for å bekrefte dette funnet.

\section{LITTERATUR}

1. Apostolova LG, Beyer M, Green AE et al. Hippocampal, caudate, and ventricular changes in Parkinson's disease with and without dementia. Mov Disord 2010; 25: 687-8.

Publisert: 1. juli 2010. Tidsskr Nor Legeforen. DOI:10.4045/tidsskr.10.0614 
(C) Tidsskrift for Den norske legeforening 2023. Lastet ned fra tidsskriftet.no 26. april 2023. 